\title{
The application of the Revised Universal Soil Loss Equation, Version 2, to evaluate the impacts of alternative climate change scenarios on runoff and sediment yield
}

\author{
S.M. Dabney, D.C. Yoder, and D.A.N. Vieira
}

\begin{abstract}
The Revised Universal Soil Loss Equation, Version 2 (RUSLE2), provides robust estimates of average annual sheet and rill erosion for one-dimensional hillslope representations. Extensive databases describing climate, soils, and management options have been developed and are widely used in the United States for conservation planning. Recent RUSLE2 enhancements allow estimation of erosion and runoff from a representative sequence of runoff events that are suitable for linkage with an ephemeral gully model. This paper reviews the sensitivity of RUSLE2 erosion estimates to possible climate change scenarios, demonstrates its ability to evaluate alternative management adaptations, and compares predictions with observations of runoff and sediment yield from a 6.6 ha $(16 \mathrm{ac})$ research watershed located near Treynor, Iowa. When applied to a representative hillslope profile with conventional tillage corn (Zea mays L.), increasing monthly temperature by $0.8^{\circ} \mathrm{C}\left(1.5^{\circ} \mathrm{F}\right)$ and rainfall depth, rainfall erosivity density, and 10-year, 24-hour rainfall depth each by $10 \%$ cumulatively increased sheet and rill erosion by $47 \%$ and increased runoff by $33 \%$, assuming there was no change in corn yield. If the climate changes decreased corn yield by $10 \%$, the overall effect was to increase soil loss for conservation planning by $63 \%$. These results demonstrate that modest and expected changes in climate will significantly increase the risk of soil erosion, and improved conservation management will be an important part of successful adaptation.
\end{abstract}

Key words: ephemeral gully erosion-deposition-geographic information system-light detection and ranging (LiDAR) — soil erosion—vegetative barrier

The Revised Universal Soil Loss Equation, Version 2 (RUSLE2), is the most recent in the family of Universal Soil Loss Equation (USLE)/RUSLE/RUSLE2 models proven to provide robust estimates of average annual sheet and rill erosion for onedimensional hillslope representations. The USDA Natural Resources Conservation Service (NRCS) routinely uses RUSLE2 for conservation planning and program eligibility determination and has developed extensive databases applicable throughout the United States to support this work (USDA NRCS 2012a).

This report describes how RUSLE2 represents climate and explores how alternative climate change and crop yield scenarios affect runoff and soil erosion predictions. Hillslope runoff sediment yield predictions delivery estimates. The approach could easily be extended to assess the likelihood of success for conservation practices under future climates by linking RUSLE2 to climate projections and crop yield responses predicted by other modeling systems.

Analysis of historical records indicates that rainfall erosivity-defined as the product of each storm's total kinetic energy and maximum 30-minute intensity summed over a period or season-generally increased in the United States during the period from 1972 to 2002, but changes were not uniform regionally nor seasonally (Hollinger et al.2002; Angel et al. 2005). Like these observations, predictions of coupled atmosphere-ocean general circulation models show temperatures and precipitation intensity and variance have risen in the past century and are likely to rise further in the next century (Dore 2005; Tebaldi et al. 2006). Average precipitation depths, in contrast, may increase or decrease for various locations and seasons (Hayhoe et al. 2007; Diodato and Bellocchi 2009; Campbell et al. 2011), with wet areas generally becoming wetter and arid areas becoming drier due to increased evaporative demand.

However, current general circulation climate change models do not provide sufficiently detailed information to allow direct calculation of rainfall erosivity because subhourly rainfall intensity information is not reliably estimated. Even current regional climate models cannot reliably predict the variables most highly correlated with erosion, such as the 30-minute maximum monthly rainfall intensity or average monthly erosivity density (Dai et al. 1999). In climate studies, precipitation intensity is frequently defined as increased daily precipitation depth rather than increased subhourly rainfall rates. To deal with this, some studies have relied on simple methods, such as a modified Fournier's index, to estimate climate change impacts on rainfall erosivity (Nearing 2001; Sauerborn et al. 2009). Others have used CLIGEN to

Seth M. Dabney is a research leader at the Watershed Physical Processes Research Unit, USDA Agricultural Research Service National Sedimentation Laboratory, Oxford, Mississippi. Daniel C. Yoder is professor of Biosystems Engineering and Soil Science, University of Tennessee, Knoxville, Tennessee. Dalmo A. N. Vieira is a physical scientist at the USDA Agricultural Research Service National Sedimentation Laboratory, State University, Arkansas. 
down-scale climatic projections (Zhang et al. 2010), although most such studies have not altered the monthly estimates of mean maximum 30-minute rainfall intensity, which are CLIGEN inputs (Yu 2005), focusing rather only on monthly rainfall, its standard deviation, and the conditional probabilities of wet days following wet or dry days. Downscaling climate change projections and predicting crop growth responses to climate change are beyond the scope of this paper. Rather, we will explore the sensitivity of RUSLE2 to observed or appropriately downscaled climate information to predict the impacts of climate change on soil erosion. When other models have been used in such sensitivity analyses, a given percentage increase in temperature, rainfall, antecedent soil water, or land cover biomass has usually resulted in a larger percentage increase in soil erosion (Nearing et al. 2005; Nunes et al. 2009).

RUSLE2 predicts a linear increase in sheet and rill erosion with increasing rainfall erosivity, which reflects the influences of both rainfall depth and rainfall intensity. Rainfall intensity effects are represented in the parameter erosivity density (energy per unit area per unit time). If both precipitation depth and erosivity density increase, these increases would be multiplicative in increasing rainfall erosivity and RUSLE2calculated sheet and rill detachment. Other suggested climate changes would also impact erosion. For example, increased temperature and rainfall would increase residue decomposition and surface roughness degradation, leaving the soil more susceptible to soil erosion. In addition, increases in the magnitude of the 10-year, 24-hour precipitation depth $\left(\mathrm{P}_{10 \mathrm{y}, 24 \mathrm{~h}}\right)$ will result in increased estimated sediment transport capacity and sediment delivery. Finally, simultaneously increased rainfall depth, erosivity density, and $\mathrm{P}_{10 \mathrm{y}, 24 \mathrm{~h}}$ would increase runoff amounts and would likely increase concentrated flow erosion in nonlinear ways.

The objectives of this study are to (1) compare official county-level RUSLE2 database climate input records to observations made at a particular research watershed, (2) to explore the sensitivity of RUSLE2 erosion estimates to changes in climatic database inputs proposed to reflect the impacts of climate change, (3) to compare RUSLE2 hillslope profile runoff and sediment delivery estimates with historical observations made at the watershed outlet during three peri- ods of varying land management practices, and (4) to demonstrate how the RUSLE2 program can be called through its API to provide spatially distributed runoff and erosion estimates in a GIS context.

\section{Materials and Methods}

Climate Representation in the Revised Universal Soil Loss Equation, Version 2. The climate data required to calculate sheet and rill erosion and sediment delivery with RUSLE2 are monthly averages for precipitation, temperature, and erosivity density, plus the location's $\mathrm{P}_{10 \mathrm{y}, 24 \mathrm{~h}}$. Thus, representation of climate change effects in RUSLE2 reduces to representation of the changes in these variables.

RUSLE2 assumes that sheet and rill erosion is linearly related to rainfall erosivity, which has proven to be a robust assumption based on many plot years of data. However, direct specification of rainfall erosivity is no longer the preferred input to RUSLE2, as one of the important innovations in RUSLE2 was introduction of the erosivity density concept (USDA ARS 2008). Erosivity density is defined as the amount of rainfall erosivity per unit of precipitation depth. Erosivity density has units of energy per unit area per unit time (MJ ha ${ }^{-1} \mathrm{~h}^{-1}$ ), and when multiplied by the depth of precipitation ( $\mathrm{mm}$ ) over an interval (event, day, month, or year), yields the appropriate average erosivity value (MJ $\mathrm{mm}$ $\left.\mathrm{ha}^{-1} \mathrm{~h}^{-1}\right)$. Specification of monthly average precipitation and monthly average erosivity density is the preferred way of describing monthly erosivity in RUSLE2, and these values are contained in all the NRCS location climate files (USDA NRCS 2012a).

Using erosivity density has several advantages over directly calculated rainfall erosivity. Because it is the ratio of storm erosivity to storm precipitation, missing data have less impact on monthly means, and a shorter period of record is needed to arrive at a stable value of this ratio than to achieve a stable absolute erosivity. Furthermore, because erosivity density was found to be relatively independent of elevation up to $3,000 \mathrm{~m}$ $(9,800 \mathrm{ft})$, RUSLE2 developers were able to develop a smoothly varying erosivity density surface for the entire nation, making it possible to calculate erosivity for each county (common use in United States) or each precipitation zone (USDA ARS 2008). Because RUSLE2 is a conservation planning tool, it is important that climate representations vary smoothly and in expected directions across geographic boundaries. The erosivity density approach allowed geographically consistent erosion predictions needed for a conservation/erosion planning tool and maximized the information that could be extracted from available 15-minute precipitation data. The effect of elevation on erosivity was reflected by defining multiple precipitation zones within counties for 11 mountainous western US states.

Crop Growth and Residue Decomposition Representation in the Revised Universal Soil Loss Equation, Version 2. RUSLE2 does not link crop growth to climate inputs. Rather, the user describes the growth and specifies the yield of vegetation, and RUSLE2 calculates the long-term effect on runoff and erosion. RUSLE2 contains algorithms that allow estimates of the timing and amount of residue creation by perennial vegetation to dynamically adjust to alternative harvest management schemes (Dabney and Yoder 2012), but even these routines are not linked to climate. The lack of a dynamic linkage with climate may appear to be a disadvantage since crop yield and the ratio of yield to residue biomass are inputs to RUSLE2 that may be expected to vary with changing climate. However, the ability to call RUSLE2 through its API from another model allows RUSLE2 to be linked to a variety of sophisticated plant growth models. The effects of climate change on crop biomass production and yield are complex. Depending on the location, effects will involve interacting with and sometimes offsetting influences of higher carbon dioxide $\left(\mathrm{CO}_{2}\right.$; increased plant growth and water use efficiency), increased temperature (temperature stress and evaporative demand, but perhaps also a longer growing period), increased or decreased rainfall amounts and variability (Hatfield et al. 2011), etc. Changes in germplasm and responses of weed, insect, and disease dynamics add to the uncertainty of future yield predictions. Rather than attempting to include such a sophisticated growth model, RUSLE2 operates on resulting inputs of vegetative biomass, canopy cover, and rootmass, leaving it to experts to define those characteristics. The USDA NRCS has developed hundreds of such vegetative descriptions based on collected data and expert opinion (USDA NRCS 2012a), defined based on a specified yield value, which can then be over-ridden by the user to increase or decrease the input parameters. RUSLE2's use of crop yield as an 
input rather than a calculated response to climate change allows the evaluation of erosion effects using outputs from any crop growth model or from an assemblage of models such as that being developed by the Agricultural Model Intercomparison and Improvement Project (AgMIP 2010).

Unlike crop growth, residue decomposition is dynamically linked to climate in RUSLE2. Generally speaking, if a climate becomes wetter and warmer, the rate of residue decomposition increases. Thus, if crop yield and rainfall erosivity remained constant, higher temperatures would increase RUSLE2 estimates of soil erosion because of reduced crop residue cover and residue biomass in the soil.

Runoff Representation in the Revised Universal Soil Loss Equation, Version 2. One expected impact of climate change is the increased importance of extreme events as threats to soil and water resources (SWCS 2007). Recently, Dabney et al. (2011b) developed procedures to extend RUSLE2 to prediction of a representative sequence of runoff events. The procedures estimate average monthly runoff, the number of runoff events per year, and the scale parameter of a gamma distribution describing the population of runoff events, thus permitting estimation of the depth of a runoff event for a user-specified return period. This was done without affecting the sheet and rill erosion estimation, which depends primarily on the total erosivity and its general time distribution and less on the actual number of events. As described by Dabney et al. (2011b), the procedures include increases to predicted monthly runoff when a location's monthly erosivity density exceeds $3 \mathrm{MJ} \mathrm{ha}^{-1} \mathrm{~h}^{-1}$ (450 $\left.\mathrm{ft}-\mathrm{tn}_{\mathrm{f}} \mathrm{ac}^{-1} \mathrm{hr}^{-1}\right)$. The predicted scale factor of the gamma distribution describing the population or runoff events is then increased by a factor equal to by the ratio of predicted annual runoff with and without the erosivity density adjustment.

The representative runoff event sequence developed by RUSLE2 and the associated sheet and rill sediment delivery to the channel system that terminates RUSLE2 hillslope flow paths are suitable for coupling with a physically based ephemeral gully model. Such a coupled system would provide a more complete estimate of water erosion and allow the assessment of climate change effects on extreme events driven by runoff in addition to effects associated with rainfall erosivity.

\section{Figure 1}

Topographic map ( $0.31 \mathrm{~m}$ contour interval) of Watershed 11 at Treynor, lowa, illustrating appropriate Revised Universal Soil Loss Equation hillslope flow paths (Renard et al. 1997, figure $5 \mathrm{~b}$ in chapter 4) as well as the extent of observed concentrated flow channels and those determined using a D-8 method based on varying minimum contributing areas from $300 \mathrm{~m}^{2}$ to $4,000 \mathrm{~m}^{2}$.

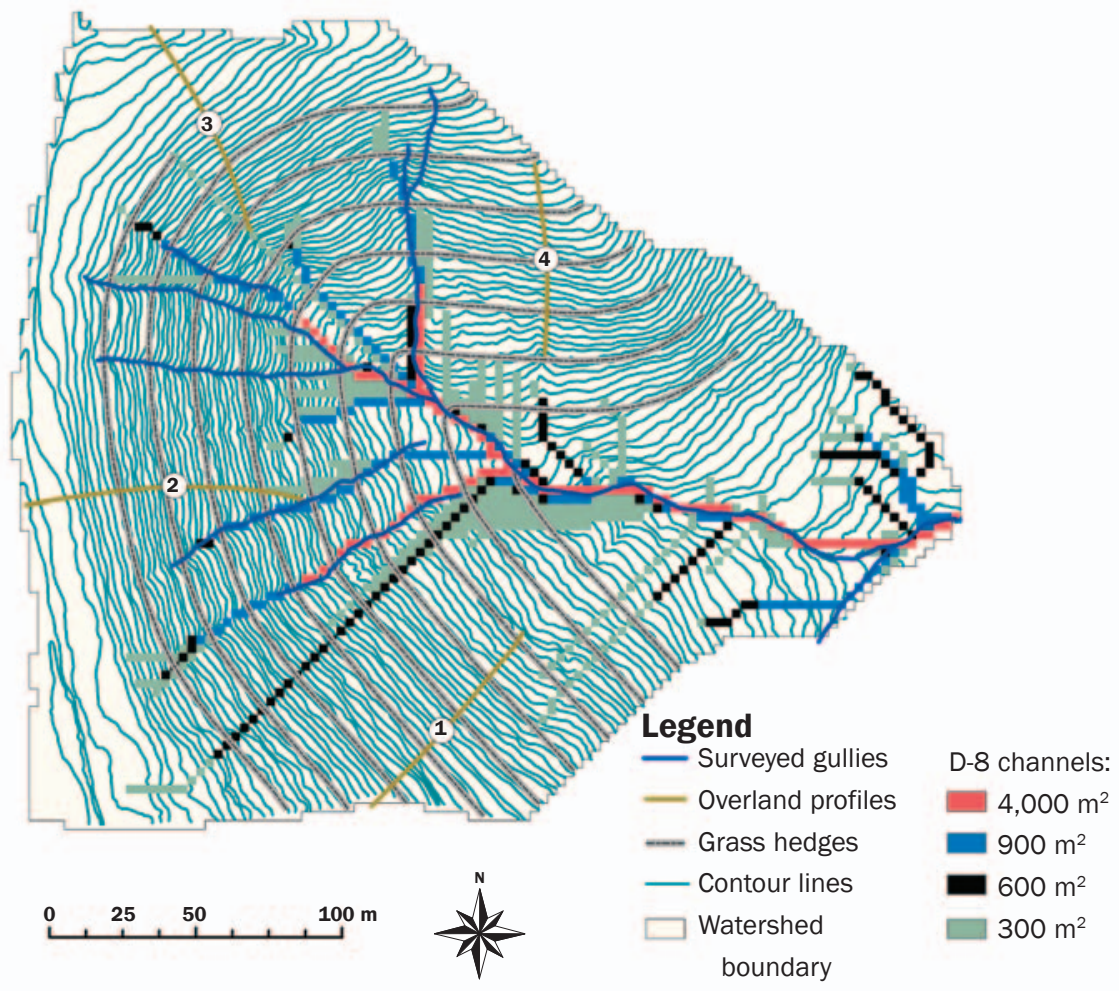

Sensitivity of Revised Universal Soil Loss Equation, Version 2, Estimates to Climate Change Scenarios. The sensitivity of RUSLE2 runoff and erosion estimates to climate variations was tested using a one-dimensional hillslope profile (profile 2, described below), modeled assuming the land was managed with conventional tillage and planted to corn (Zea mays L.). Input climatic and crop yield variables varied alone and in combination and included the following: increasing monthly temperature by $0.8^{\circ} \mathrm{C} \quad\left(1.5^{\circ} \mathrm{F}\right)$, increasing monthly precipitation depth by $10 \%$, increasing monthly erosivity density by $10 \%$, increasing the depth of $\mathrm{P}_{10 \mathrm{y}, 24 \mathrm{~h}}$ by $10 \%$, and increasing or decreasing crop yield levels by $10 \%$. The rationale and justification for these scenarios is discussed below.

Observed Rainfall and Runoff. RUSLE2 rainfall inputs and runoff and erosion predictions were compared with measured values from the USDA Agricultural Research Service Deep Loess Research Station located near Treynor, Iowa (Karlen et al. 2009), with rainfall observations collected from adjacent weighing (gauge 118, 1964 to1993) and tip- ping bucket (gauge 117, 1994 to 2004) rain gauges. Rainfall erosivity was determined from rain gauge data using the Rainfall Intensity Summarization Tool (USDA ARS 2011). Daily observations of runoff and sediment yield were collected from 1975 to 2002 at the outlet of Watershed 11 (Rachman et al. 2008), a 6.6 ha (16 ac) drainage area located adjacent to the rain gauges. A topographic map of the watershed was used as a figure in the RUSLE documentation (figure $5 b$ in chapter 4 of Renard et al. 1997) to illustrate the proper representation of four hillslope flow paths (labeled 1 to 4 , figure 1 ) that extend from ridge tops to areas of concentrated flow reflected in the topography. The hillslope profile modeled in this study comprises hillslope flowpath 2 from figure 1, coupled with local climate, soil, and management information.

Throughout the period of the runoff and erosion record, a grassed waterway was located in the lower portion of the watershed, and the field was tilled and planted with contour rows. Beginning in 1991, contour grass hedges were established (figure 1). Hedges were approximately $1 \mathrm{~m}(3.3 \mathrm{ft})$ wide and were spaced 
$15.4 \mathrm{~m}(50.5 \mathrm{ft})$ apart to accommodate 16 crop rows. From 1975 through 1996, the field was farmed with contour-planted conventional tillage corn. From 1997 to 1999, the field was planted with no-till soybean (Glycine $\max$ L.), and a no-till corn-soybean rotation was used from 2000 to 2002 (Rachman et al. $2008)$. Average corn yield for the period from 1987 to 1996 was $7.6 \mathrm{Mg} \mathrm{ha}^{-1}\left(6,900 \mathrm{lb} \mathrm{ac}^{-1}\right)$ (Eghball et al. 2000).

One-Dimensional Revised Universal Soil Loss Equation, Version 2, Simulations. RUSLE2 runoff and erosion simulations are generally conducted on one-dimensional hillslope flow paths, called profiles, that extend from the top of a hill to the point where the flow path intersects a concentrated flow path. RUSLE2 profiles consists of combinations of climate, topographic, soil, and management practice descriptions that may vary within segments of the profile. In this study, RUSLE2 simulations were performed for the flow path defined as "profile 2" in figure 1. To facilitate comparison of RUSLE2 predictions with historical observations, three management systems that mimicked historical management of the watershed were evaluated: conventional tillage corn yielding 7.6 $\mathrm{Mg} \mathrm{ha}^{-1}\left(6,900 \mathrm{lb} \mathrm{ac}^{-1}\right)(\mathrm{CN})$, similar conventional tillage corn with grass hedges $(\mathrm{CH})$, and no-till soybean yielding 3.0 $\mathrm{Mg} \mathrm{ha}^{-1}$ (45 $\mathrm{bu} \mathrm{ac}^{-1}$ ) rotated with no-till corn yielding 7.6 $\mathrm{Mg} \mathrm{ha}^{-1}(\mathrm{NH})$. The upper $24.2 \mathrm{~m}(79.4 \mathrm{ft})$ of profile 2 was Marshall silty clay loam, and the balance of the profile was Monona silt loam (figure 2). The other three profiles identified in figure 1 were run only for the first of these land management scenarios. The four profiles varied in topography (figure 1) and had slightly different soil types (figure 2). Properties of the soils were obtained from the official NRCS RUSLE2 database for Pottawattamie County, Iowa (USDA NRCS 2012a). All of the watershed soils were hydrologic soil group B in the official database, unlike the generic silt loam soil with hydrologic soil group C that was used in simulation of Dabney et al. (2011a). The predominant watershed soil was Monona silt loam (fine-silty, mixed, superactive, mesic Typic Hapludolls). Input RUSLE2 climate database values for Pottawattamie County, Iowa, were from the official RUSLE2 database (USDA NRCS 2012a).

Two-Dimensional Revised Universal Soil Loss Equation, Version 2, Watershed Representation. The availability of high res-

\section{Figure 2}

General soils map for a region including Watershed 11 at Treynor, lowa, from the Natural Resources Conservation Service Web Soil Survey site (USDA NRCS 2012b) showing the locations of observed ephemeral and classical gullies.

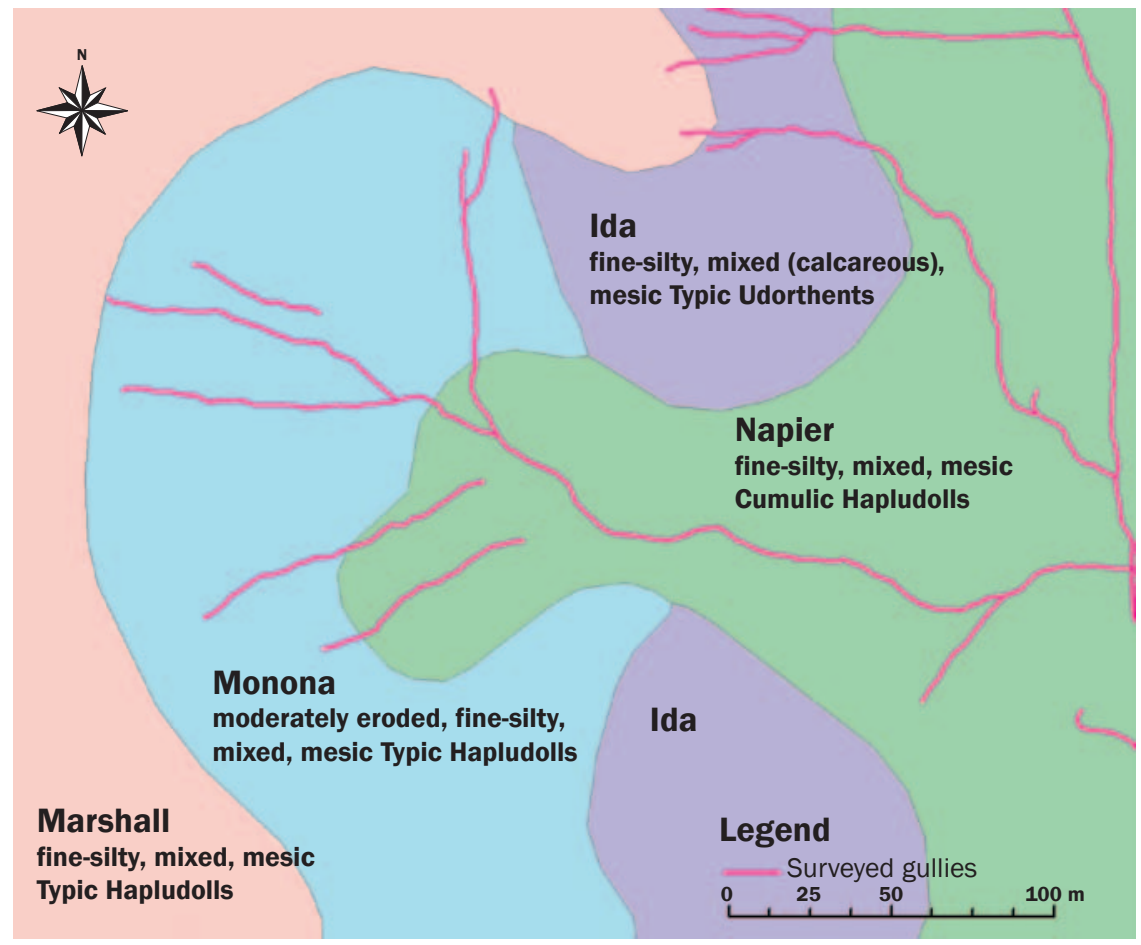

\section{Figure 3}

Conceptual approach for extending the Revised Universal Soil Loss Equation, Version 2 (RUSLE2), to a distributed geographic information system (GIS) application. (a) Starting with each cell containing a channel (black outline), a GIS algorithm analyzes the flow directions map to determine the connectivity and computational sequence of the cells that compose a profile. The figure shows three profiles on each side of the channel, identified in different colors. Each cell may have varying soil and management attributes. (b) RUSLE2 determines effective slope length in each cell by taking appropriate accounting for topographic, soil, and management effects on local erosion estimates.

(a)

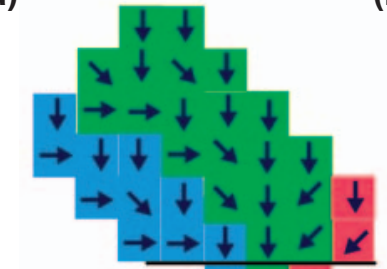

Channel

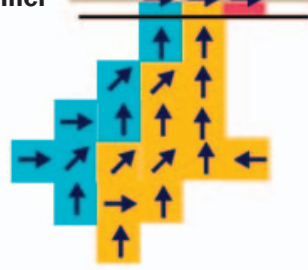

(b)

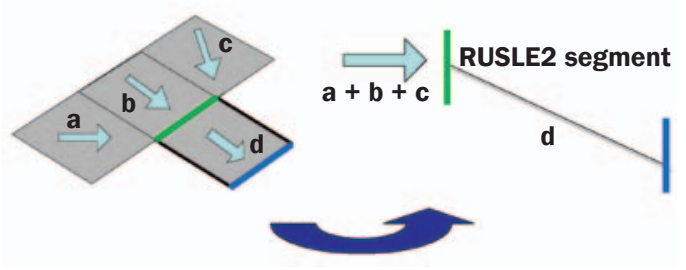

Slope length for each cell is calculated from the ratio of runoff leaving the cell to that generated within the cell, thus accounting for topographic, soil, and management effects. 


\section{Table 1}

Sensitivity of Revised Universal Soil Loss Equation, Version 2, predictions for profile \#2 (figure 1) to changes in climatic and crop yield inputs. A " 1 " in the case row signifies an input used. A "o" signifies that a default or standard value was used in the case.

\begin{tabular}{|c|c|c|c|c|c|c|c|c|c|c|c|c|c|}
\hline Case & $Y_{0}$ & $\mathbf{Y}_{+}$ & $\mathbf{Y}_{-}$ & $\mathbf{T}_{+}$ & $\mathbf{P}_{+}$ & $\mathbf{E}_{+}$ & $\mathbf{P}_{10+}$ & SY $\left(\mathrm{Mg} \mathrm{ha}^{-1}\right)$ & $G_{c p}\left(M g h^{-1}\right)$ & $\mathrm{Q}(\mathrm{mm})$ & epy (mm) & $\sigma(\mathrm{mm})$ & $Q_{1}(\mathrm{~mm})$ \\
\hline 1 & 1 & 0 & 0 & 0 & 0 & 0 & 0 & 58 & 65 & 65 & 15 & 9.1 & 16 \\
\hline & & & & & & & & \multicolumn{6}{|l|}{ Relative value } \\
\hline 2 & 1 & 0 & 0 & 1 & 0 & 0 & 0 & 1.05 & 1.02 & 1.01 & 1.04 & 1.00 & 1.00 \\
\hline 3 & 1 & 0 & 0 & 0 & 1 & 0 & 0 & 1.18 & 1.17 & 1.26 & 1.22 & 1.19 & 1.24 \\
\hline 4 & 1 & 0 & 0 & 0 & 0 & 1 & 0 & 1.24 & 1.23 & 0.97 & 0.87 & 1.31 & 1.18 \\
\hline 5 & 1 & 0 & 0 & 0 & 0 & 0 & 1 & 1.08 & 1.08 & 1.02 & 0.96 & 0.88 & 0.82 \\
\hline 6 & 1 & 0 & 0 & 0 & 1 & 1 & 0 & 1.33 & 1.33 & 1.32 & 1.09 & 1.48 & 1.47 \\
\hline 7 & 1 & 0 & 0 & 1 & 1 & 1 & 0 & 1.38 & 1.38 & 1.34 & 1.13 & 1.46 & 1.47 \\
\hline 8 & 1 & 0 & 0 & 1 & 1 & 1 & 1 & 1.46 & 1.47 & 1.33 & 1.09 & 1.34 & 1.35 \\
\hline 9 & 0 & 1 & 0 & 0 & 0 & 0 & 0 & 0.92 & 0.90 & 0.98 & 1.00 & 1.00 & 1.00 \\
\hline 10 & 0 & 1 & 0 & 1 & 1 & 1 & 1 & 1.33 & 1.33 & 1.31 & 1.09 & 1.34 & 1.35 \\
\hline 11 & 0 & 0 & 1 & 0 & 0 & 0 & 0 & 1.12 & 1.12 & 1.02 & 1.00 & 1.00 & 1.00 \\
\hline 12 & 0 & 0 & 1 & 1 & 1 & 1 & 1 & 1.63 & 1.63 & 1.34 & 1.09 & 1.34 & 1.35 \\
\hline
\end{tabular}

Notes: Case 1 is the baseline case using the official Pottawattamie County, lowa, climate and measured average corn yield inputs to which all other cases are compared. $Y_{0}=$ base corn grain yield of $7.6 \mathrm{Mg} \mathrm{ha}^{-1} . \mathrm{Y}_{+}=10 \%$ increase in yield. $\mathrm{Y}_{-}=10 \%$ decrease in yield. $\mathrm{T}_{+}=$monthly temperature increased by $0.8^{\circ} \mathrm{C} . \mathrm{P}_{+}=10 \%$ increase in monthly precipitation. $\mathrm{E}_{+}=10 \%$ increase in monthly erosivity density. $\mathrm{P}_{10^{+}}=10 \%$ increase in the 10 -year, 24-hour rainfall depth. $S Y=$ average annual sediment yield. $G_{c p}=$ average annual soil loss for conservation planning. $Q=$ average annual runoff. epy $=$ runoff events per year. $\sigma=$ runoff event gamma distribution scale parameter (assuming shape parameter $\alpha=0.5$ ). $Q_{1}=$ depth of runoff event with a 1-year return period.

olution topographic information from real time kinematic global positioning system (RTK-GPS) or light detection and ranging (LiDAR) surveys creates the opportunity to automatically determine the locations of concentrated flow areas and thus the ends of appropriate RUSLE2 hillslope profiles, using GIS tools. Once flow vectors and channels are identified, other GIS tools permit RUSLE2 hillslopes to be defined, including flow convergence effects (figure 3a). RUSLE2 has been modified to allow cell-based computations, where the effective contributing "slope length" for each raster is based on the ratio of runoff leaving the cell to that generated within the cell, so that upslope variation in management and soil that affect runoff amounts is considered in determining the effective slope length for each raster (figure $3 \mathrm{~b})$. These developments allow RUSLE2 to be called by a shell program through the RUSLE2 API and to return a distributed assessment of hillslope erosion, deposition, and delivery of runoff and sediment to concentrated flow channels.

The representative runoff event sequence predicted by RUSLE2 depends on soil, management, and climate inputs. When applied to a domain within which soil and/or management may vary, it is desirable that a common event sequence be applied to all areas of the field. To facilitate this, RUSLE2 calculates the runoff event sequence based on the proper- ties of an "internal profile" that may have the same or different soil and management properties as segments of the "parent profile." In this 2-D example, the internal profile management was set as "continuous fallow" to represent a worst-case event sequence, and the internal profile soil was set to a generic silt loam soil with hydraulic class "B." The effect of internal profile properties on sheet and rill erosion estimates is limited to the errors introduced by estimating erosion based on a limited number of discrete events rather than as the sum of 365 smoothly varying events per year.

Because a shell program selects soil, management, and climate database files and calls the RUSLE2 dynamic-link library (DLL) through its API, crop yield levels could be varied to reflect the influence of spatial variation among management zones within the simulation domain. Similarly, both yields and climate descriptions could be varied to simulate climate change impacts. In the example presented herein, however, the same RUSLE2 soils and management systems used in the 1-D profile simulations were applied to the 2-D distributed simulations.

\section{Results and Discussion}

Observed Rainfall Versus Expected Rainfall for Conservation Planning. Data are summarized in terms of three observation periods when runoff and erosion were measured for common land use, with these periods designated as CN (1975 to 1991), CH (1991 to 1997), and NH (1997 to 2007). Precipitation and erosivity density - and therefore rainfall erosivity patterns-observed during the three observation periods at the Treynor site showed some variability but were generally similar to those available for Pottawattamie County in the official NRCS database (figure 4). The official database is intended for conservation planning, and 30-year average values from many locations have been smoothed using GIS techniques to give consistent trends over broad geographic areas (USDA ARS 2008). Generally speaking, rainfall erosivity at the Treynor site was higher during June and August than in the official database. Annual rainfall erosivity for Pottawattamie in the official database was 2,650 MJ mm ha ${ }^{-1} \mathrm{~h}^{-1}$ (156 hundreds of $\mathrm{ft}-\mathrm{tn}$ in $\mathrm{ac}^{-1} \mathrm{hr}^{-1}$ ) compared to $3,610 \mathrm{MJ} \mathrm{mm} \mathrm{ha} \mathrm{m}^{-1}$

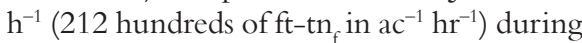
$\mathrm{CN}, 3,020 \mathrm{MJ} \mathrm{mm} \mathrm{ha} \mathrm{h}^{-1} \mathrm{~h}^{-1}$ (177 hundreds of $\mathrm{ft}-\mathrm{tn}_{\mathrm{f}}$ in $\mathrm{ac}^{-1} \mathrm{hr}^{-1}$ ) during $\mathrm{CH}$, and 3,190 MJ $\mathrm{mm} \mathrm{ha} \mathrm{h}^{-1} \mathrm{~h}^{-1}$ (187 hundreds of $\mathrm{ft}-\mathrm{tn}_{\mathrm{f}}$ in $\mathrm{ac}^{-1}$ $\mathrm{hr}^{-1}$ ) during $\mathrm{NH}$ at the Treynor site.

Potential Climate Change Impacts on Runoff, Erosion, and Sediment Yield. The impacts of 12 climate scenarios on RUSLE2 predictions of runoff and erosion are summarized in table 1. In this table, the effects of changing individuals and combined climate variables and crop yield levels are reported 


\section{Figure 4}

Observed monthly (a) rainfall depth, (b) erosivity density, and (c) rainfall erosivity during three periods (1975 to 1991 [CN: conventional tillage and no hedge], 1991 to 1997 [CH: conventional tillage and grass hedge], and 1997 to 2002 [NH: no-till and hedge]) and the corresponding long-term values from the official USDA Natural Resources Conservation Service Revised Universal Soil Loss Equation, Version 2, database for Pottawattamie, lowa (R2).

(a)

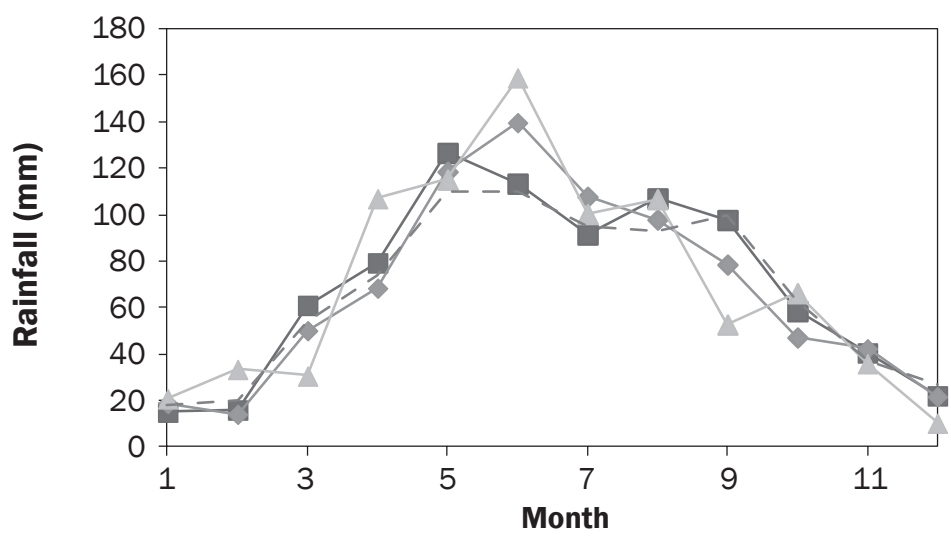

(b)

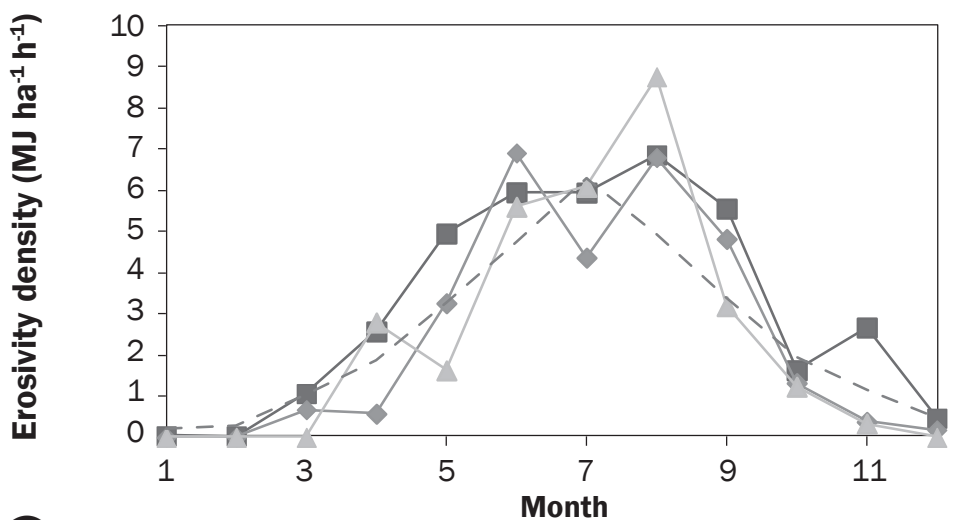

(c)

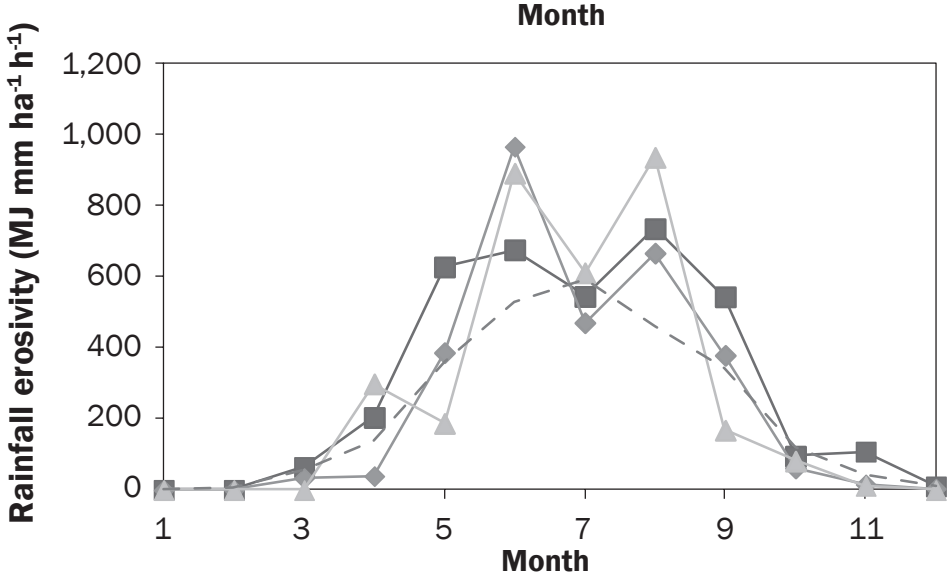

Legend

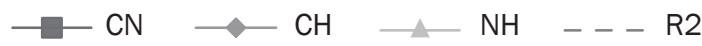

relative to the baseline values reported as Case 1. The ability of RUSLE2 to vary crop yield independently from climate variables facilitates elucidation of the separate and combined influences of climate on physical and biological processes and allows the results of a variety of crop growth models to be interpreted in terms of their effect on soil conservation.

Increasing monthly temperature by $0.8^{\circ} \mathrm{C}$ $\left(1.5^{\circ} \mathrm{F}\right)($ Case 2$)$ resulted in a $5 \%$ increase in sediment yield, a $2 \%$ increase in soil loss for conservation planning, and a $1 \%$ increase in annual runoff. These results reflect the increased decomposition of crop residue in a warmer climate so that residue biomass and cover would be reduced even if rainfall and crop yield remained constant. Increasing rainfall 10\% (Case 3) increased sediment yield by $18 \%$, soil loss for conservation planning by $17 \%$, and runoff by $26 \%$. The number and size of runoff events per year are predicted to be increased about $20 \%$. These effects result from the combined influences of increased rainfall erosivity and increased decomposition of crop residue and surface roughness, which in turn increases the runoff curve number. Increasing rainfall intensity (erosivity density, Case 4) by $10 \%$ has similar effects on increasing erosion and sediment yield and runoff event size but has little effect on total runoff amounts and decreases the number of runoff events per year. The combined effect of increasing both rainfall amount and intensity (Case 6) is an increase in annual runoff and erosion of about $33 \%$ and an increase in the 1 -year runoff event depth of nearly $50 \%$, which would likely greatly increase the driving forces of ephemeral gully erosion. Increasing temperature, rainfall, erosivity density, and the $\mathrm{P}_{10 \mathrm{v}, 24 \mathrm{~h}}$ each by $10 \%$ (Case 8 ) results in about a $47 \%$ increase in erosion, a $33 \%$ increase in runoff, and a $35 \%$ increase in the depth of the runoff event with a 1-year return period.

Crop yield variation in response to climate change can be complex (Hatfield et al. 2011). In a steady climate, RUSLE2 algorithms predicted yield variation has more effect on soil erosion than it does on runoff (Cases 9 and 11). Increasing yield $10 \%$ results in a $10 \%$ reduction in soil loss for conservation planning (Case 9), while a 10\% decrease in yield results in a $12 \%$ increase in soil loss for conservation planning (Case 11). The worst case scenario investigated is an increase in temperature and rainfall combined with a decrease in crop yield (case 12), which results in a $63 \%$ increase in sheet and rill erosion as well as increases in ephemeral gully erosion expected from a $34 \%$ increase in annual runoff and a 
Table 2

Comparison of climatic inputs for Pottawattamie County, lowa, adjusted inputs under tested climate change scenarios, and climatic inputs for Page County, lowa, and Harrision County, Missouri.

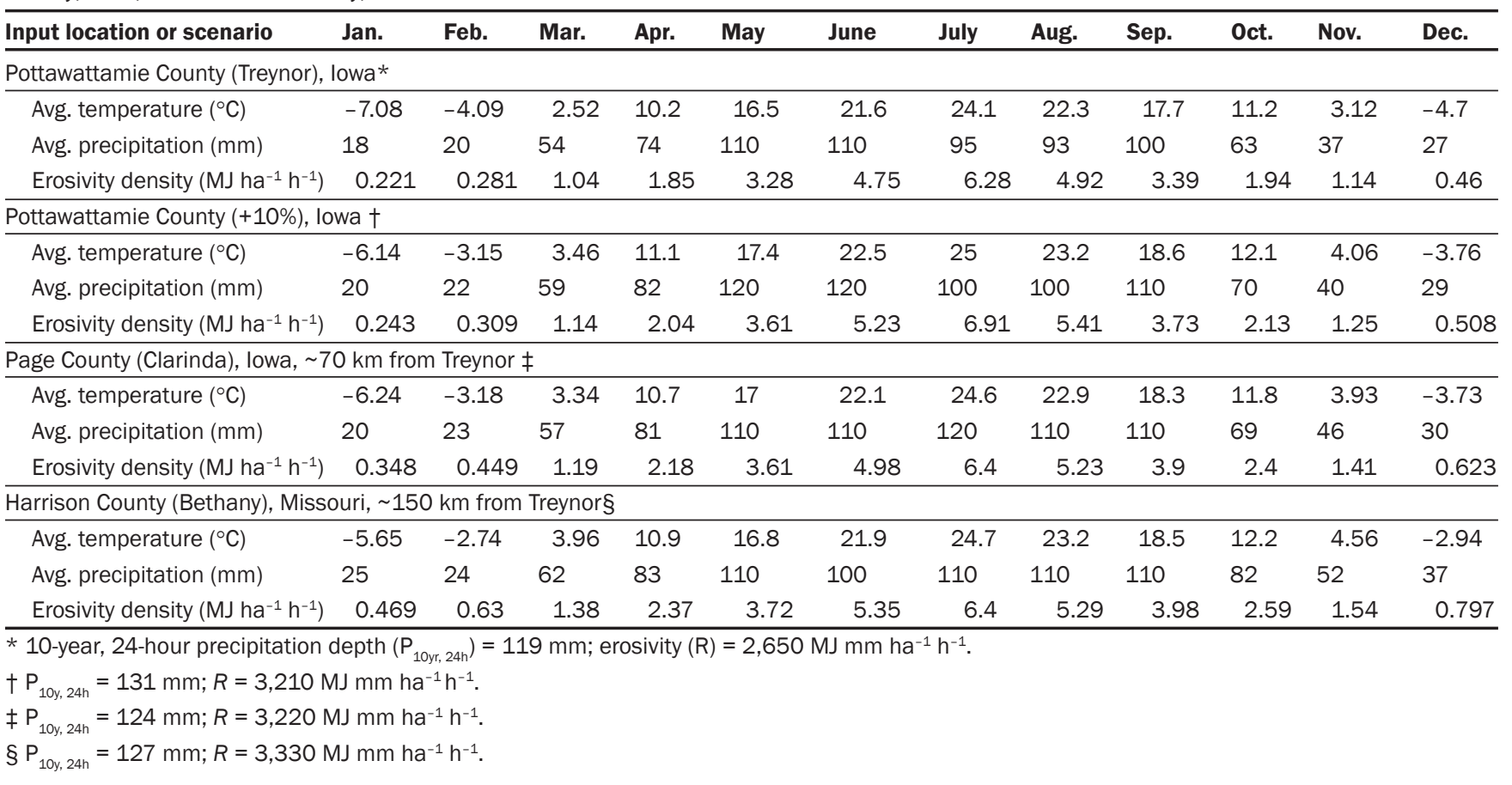

$35 \%$ increase in the depth of a runoff event with a 1-year return period.

The climate scenarios created by increasing temperature by $0.8^{\circ} \mathrm{C}\left(1.5^{\circ} \mathrm{F}\right)$ and increasing rainfall parameters by $10 \%$ are similar to values found in the official NRCS database for nearby locations (table 2). For example, increasing the rainfall depth and erosivity density each by $10 \%$ increases the resulting rainfall erosivity $(R)$ factor from 2,650 to 3,210 MJ mm ha ${ }^{-1} \mathrm{~h}^{-1}$ (156 to 189 hundreds of $\mathrm{ft}-\mathrm{tn}_{\mathrm{f}}$ in $\mathrm{ac}^{-1} \mathrm{hr}^{-1}$ ) at Treynor, Iowa. This higher value is essentially equal to the 3,220 MJ mm ha ${ }^{-1} \mathrm{~h}^{-1}$ (189 hundreds of $\mathrm{ft}-\mathrm{tn}_{\mathrm{f}}$ in $\mathrm{ac}^{-1} \mathrm{hr}^{-1}$ ) currently found in the database for Clarinda, Iowa, located about $70 \mathrm{~km}$ (43 mi) to the southeast of Treynor, and is less than the 3,330 MJ mm ha ${ }^{-1} \mathrm{~h}^{-1}$ (196 hundreds of $\mathrm{ft}-\mathrm{tn}_{\mathrm{f}}$ in $\mathrm{ac}^{-1} \mathrm{hr}^{-1}$ ) found in the database for Bethany, Missouri, located about 150 km (93 mi) from Treynor. Thus, the level of changes investigated (and anticipated in the next 50 to 100 years) did not create conditions that are outside the range of the data used to derive the statistical algorithms that are relied upon in RUSLE2 to predict runoff and erosion amounts or runoff event populations.

One-Dimensional Revised Universal Soil Loss Equation, Version 2, Predictions Compared to Observed Runoff, Erosion, and Sediment Yield. RUSLE2 runs were performed for the four profiles illustrated in figure 1 for the $\mathrm{CN}$ period with conventional tillage corn without grass hedges (table 3). RUSLE2-predicted runoff from all profiles was similar, so only an average is reported. This average was about 38\% greater than the observed runoff during the $\mathrm{CN}$ period. Part of this difference may be due to the fact that the RUSLE2 simulation did not include a representation of the grassed waterway located in the lower portion of the watershed, where infiltration might be higher. Examination of the temporal patterns of runoff (figure 5) indicates that the pattern of peak runoff occurring during the summer was correctly mimicked. The Nash-Sutcliffe model efficiency coefficient (Moriasi et al 2007) for uncalibrated predicted monthly runoff amounts was $0.35(n=36)$.

The predicted distribution of runoff events, reflected in the number of runoff events per year and the gamma distribution parameters, resulted in a reasonable match for predicting the magnitude of daily runoff amounts for events of varying return period (figure 6). Considering that this population had no local calibration, the results provide support for the assertion that RUSLE2 runoff event outputs could be productively coupled with a process-based model to estimate ephemeral gully erosion. The results also suggest that
RUSLE2 can be used to predict not only average annual soil loss, but also the magnitude of extreme events that may occur as a result of climate change if climate downscaling models can correctly estimate climate change effects on crop yield and RUSLE2 climate descriptions.

Estimated sediment yield from the four profiles to the concentrated flow channels varied from 49 to $64 \mathrm{Mg} \mathrm{ha}^{-1} \mathrm{y}^{-1}$ (22 to 29 tn $\left.\mathrm{ac}^{-1} \mathrm{yr}^{-1}\right)$. All of these values exceeded measured sediment yield at the watershed outlet and exceeded the watershed average erosion rate estimated with the distributed 2-D RUSLE2 application (table 3). These profiles were all located on the steeper-thanaverage portions of the watershed (figure 1), so average erosion of these profiles would be expected to be greater than that of the watershed average that includes flatter areas.

No consideration of erosion or deposition in the channels was made in either the profile or distributed RUSLE2 predictions in this study, as these would have required a complete channel erosion and deposition model. Fiener and Auerswald (2003) reported that, depending on management, grassed waterways were important sinks for eroded sediment. Such deposition is probably a reason why the observed watershed sediment yield is lower than the hillslope 
Figure 5

(a, c, and e) Observed rainfall, runoff, and sediment yield for Watershed 11 in Treynor, lowa, during three management periods ([a] conventional tillage and no hedge, 1975 to 1991; [c] conventional tillage and grass hedge, 1991 to 1997; and [e] no-till and grass hedge, 1997 to 2002) and (b, $\mathrm{d}$, and $\mathrm{f}$ ) the predictions of the Revised Universal Soil Loss Equation, Version 2, for profile 2 (figure 1) based on (b and d) a $7.6 \mathrm{Mg}^{-1}$ corn grain yield ([b] conventional tillage and no hedge and [d] conventional tillage and grass hedge) or (f) $7.6 \mathrm{Mg} \mathrm{ha}^{-1}$ corn rotated with $3 \mathrm{Mg}^{-1} \mathrm{soybean}^{-1}$ yield (no-till and grass hedge) and 30-year average climatic inputs.

(a)

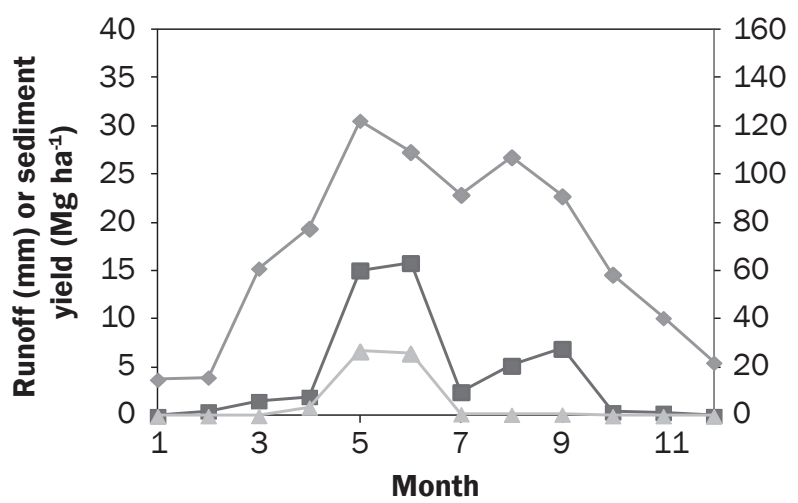

(c)

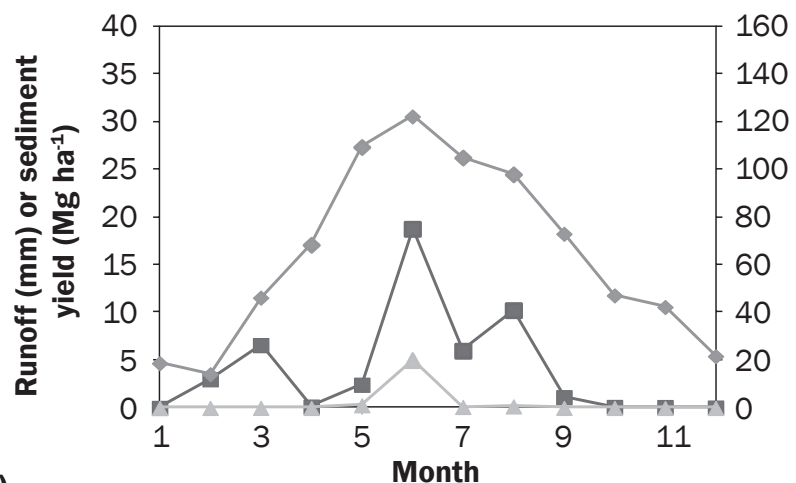

(e)

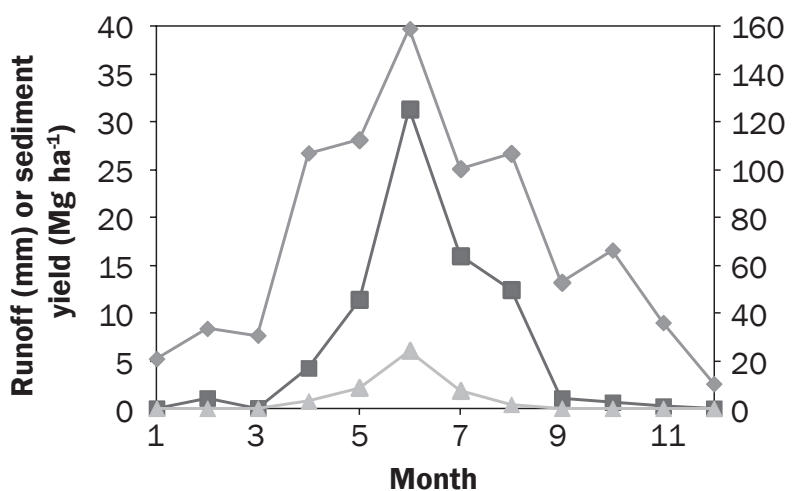

Legend

$\rightarrow$ Runoff (b)

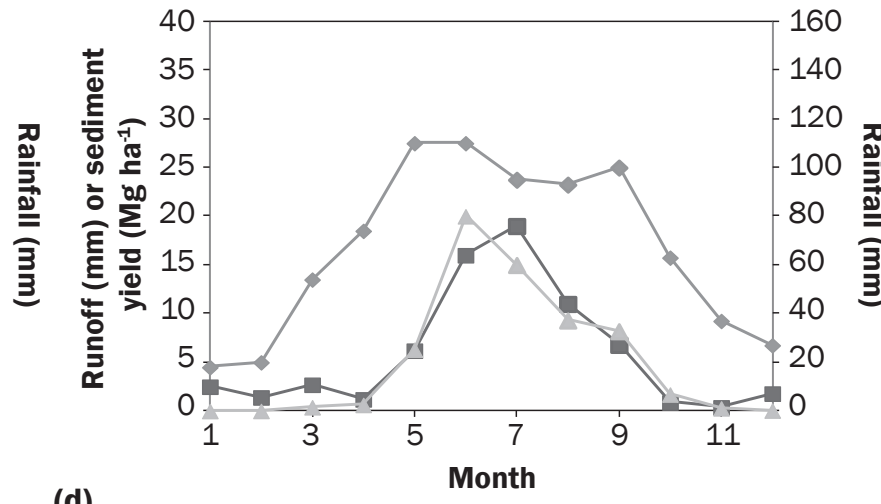

(d)

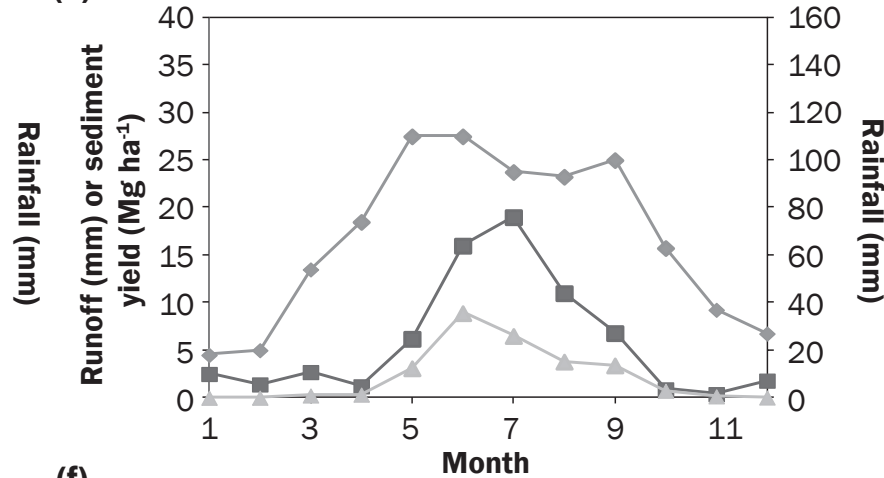

(f)

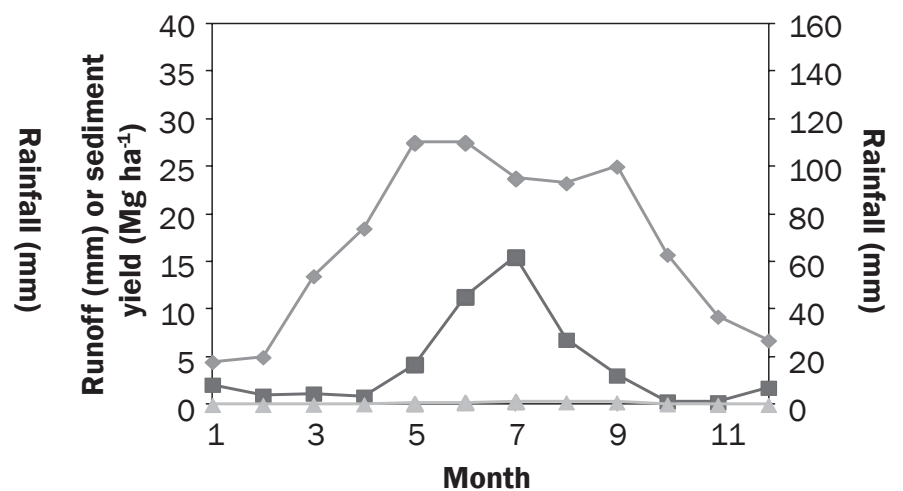

sediment yield estimates during the $\mathrm{CN}$ period. Conversely, ephemeral gully channel erosion is the likely reason why the observed watershed sediment yield is higher than the RUSLE2 sheet-and-rill erosion predictions during the NH period.
Two-Dimensional Distributed Predicted Erosion Patterns. Application of RUSLE2 to the 2-D watershed representation resulted in a complex pattern of erosion and deposition (figure 7). The average of erosion and deposition on all the rasters of the domain represents the watershed average hillslope sediment yield to the channel system. For the $\mathrm{CH}$ period (figure 7), this average was 35 $\mathrm{Mg} \mathrm{ha}^{-1} \mathrm{y}^{-1}\left(15.6 \mathrm{tn} \mathrm{ac}^{-1} \mathrm{y}^{-1}\right.$ ) (table 3), a value lower than that from the four representative profiles on the steeper-than-average parts of 
the field and larger than the observed sediment delivery from the watershed outlet.

Comparison of treatment effects involving grass hedges $(\mathrm{CH})$ and no-till $(\mathrm{NH})$ was limited to profile 2 and the distributed watershed version. In both modeling and field observations, addition of grass hedges reduced sediment yield by more than $50 \%$. Predicted hedge effects on runoff reduction were modest $(4 \%)$, which was similar to the $7 \%$ reduction predicted when WEPP was applied to this watershed (Rachman et al. 2008). When cropping was converted to no-till, RUSLE2 predicted $>90 \%$ reductions in hillslope sediment yield and also predicted $>20 \%$ reduction in runoff. In contrast, measured watershed runoff and sediment yield increased during the $\mathrm{NH}$ period relative to the $\mathrm{CH}$ period. A similar measured increase in runoff during these years of no-till management was observed in an adjacent watershed by Karlen et al. (2009). The increased measured erosion during this period is attributed to ephemeral gully erosion driven by increased runoff and may reflect the greater than average precipitation that occurred during the NH period (table 3). Tomer et al. (2007) reported sediment depositional patterns in forested riparian buffer that corresponded to the outlets of ephemeral gullies located just north of the outlet of Watershed 11 (figure 2).

The modeled distributed runoff and hillslope sediment yield results from the representative event sequence are physically meaningful and are suitable for linkage with a physically based channel erosion model to separately estimate erosion or deposition in channels (Dabney et al. 2011b). Unfortunately, no such model is currently available that can handle the complex networks of gully channels predicted by the D-8 (deterministic eight-node) flow accumulation algorithm (figure 7) or observed in the field (figure 2). There is a pressing need for the development of a robust and flexible ephemeral gully erosion model and for suitable ways to describe the initial channel hydraulic properties and gully soil erodibility properties in order to provide comprehensive estimates of field-scale soil erosion by water and to properly credit the conservation effects and optimal placement of conservation practices.

\section{Table 3}

Official Revised Universal Soil Loss Equation, Version 2 (RUSLE2), Pottawattamie County average annual rainfall and erosivity and observed and predicted average annual runoff and sediment yield (SY) for Watershed 11 near Treynor, lowa, using "continuous fallow" in the internal RUSLE2 profile to create a common representative storm sequence for all soil and land management combinations. $\mathrm{CN}$ is conventional tillage corn yielding $7.6 \mathrm{Mg} \mathrm{ha}^{-1}$; $\mathrm{CH}$ is conventional tillage corn with grass hedges; and $\mathrm{NH}$ is no-till soybean yielding $3.0 \mathrm{Mg} \mathrm{ha}^{-1}$ rotated with no-till corn yielding $7.6 \mathrm{Mg} \mathrm{ha}^{-1}$ with grass hedges.

\begin{tabular}{lcccc}
\hline Parameter & $\begin{array}{c}\text { Pottawattamie } \\
\text { County }\end{array}$ & $\begin{array}{c}\text { CN (1975 } \\
\text { to 1991) }\end{array}$ & $\begin{array}{c}\text { CH (1991 } \\
\text { to 1997) }\end{array}$ & $\begin{array}{c}\text { NH (1997 } \\
\text { to 2002) }\end{array}$ \\
\hline Annual rainfall (mm) & 801 & 811 & 766 & 835 \\
Annual erosivity (MJ mm ha-1 $\left.\mathrm{h}^{-1} \mathrm{y}^{-1}\right)$ & 2,650 & 3,610 & 3,020 & 3,190 \\
Runoff observed (mm) & - & 50 & 48 & 78 \\
Runoff predicted (mm) & - & 69 & 66 & 47 \\
Observed SY (Mg ha-1 $\left.\mathrm{y}^{-1}\right)$ & - & 14.6 & 5.6 & 11.3 \\
Profile 1 (75 m, 13\%)* SY $\left(\mathrm{Mg} \mathrm{ha}^{-1} \mathrm{y}^{-1}\right)$ & - & 49 & - & - \\
Profile 2 $(94 \mathrm{~m}, 13 \%) \mathrm{SY}\left(\mathrm{Mg} \mathrm{ha}^{-1} \mathrm{y}^{-1}\right)$ & - & 63 & 28 & 1.5 \\
Profile 3 $(77 \mathrm{~m}, 11 \%) \mathrm{SY}\left(\mathrm{Mg} \mathrm{ha}^{-1} \mathrm{y}^{-1}\right)$ & - & 51 & - & - \\
Profile 4 $(65 \mathrm{~m}, 13 \%) \mathrm{SY}\left(\mathrm{Mg} \mathrm{ha}^{-1} \mathrm{y}^{-1}\right)$ & - & 64 & - & - \\
Distributed hillslope SY $\left(\mathrm{Mg} \mathrm{ha}^{-1} \mathrm{y}^{-1}\right)$ & - & 35 & 20 & 0.4 \\
\hline
\end{tabular}

* Profile flow path length and average steepness given parenthetically.

\section{Figure 6}

Comparison of runoff event depths for events of varying return periods based upon observations ( 1975 to 2002) and predictions (with no local calibration) of the number of runoff events per year (epy) and gamma distribution shape $(\alpha)$ and scale $(\sigma)$ parameters (Dabney et al. 2011b).

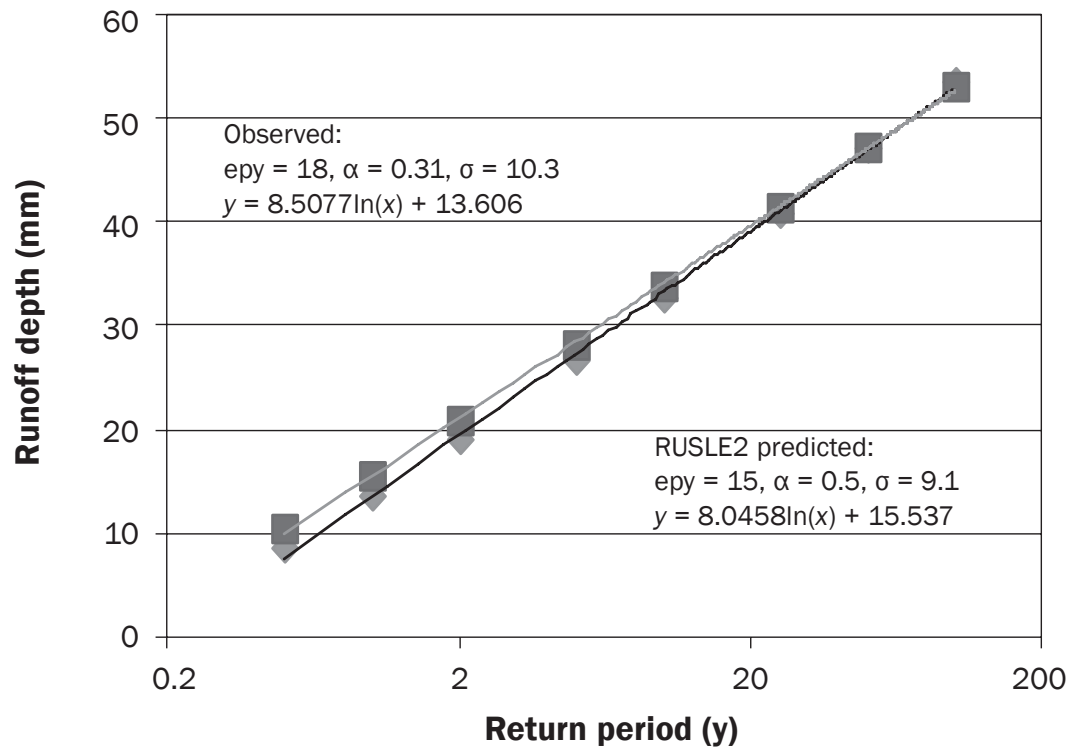

Legend

Observed 


\section{Summary and Conclusions}

RUSLE2 predictions of runoff, erosion, and sediment yield were compared with observations collected at the Watershed 11 research watershed near Treynor, Iowa, during the period from 1995 to 2002. Observed precipitation patterns were found to be generally consistent with the average values found in the official NRCS RUSLE2 database. Estimated soil erosion rates on four representative profiles within Watershed 11 were higher than the modeled watershed average sheet and rill erosion rate and higher than the observed sediment delivery at the watershed outlet. The higher estimated erosion rates on the representative profiles were expected because they represent the critical parts of a field that are typically the focus of conservation planning activities. If conservation is adequate on these critical slopes, conservation will also be adequate everywhere else.

An example of a RUSLE2 distributed version was presented that allowed spatial patterns of erosion and deposition to be visualized at a $3 \mathrm{~m}(9.8 \mathrm{ft})$ resolution. The distributed RUSLE2 output also provides the necessary inputs for linkage with a processbased ephemeral gully model.The conceptual basis for the distributed calculations was presented, showing how slope length and steepness are determined for each raster cell in such a way that realistically accounts for flow convergence and spatial variation in soil and land management properties.

The effects of climate change on expected runoff and erosion amounts were explored by varying the official RUSLE2 climate record of Pottawattamie County, Iowa. Monthly temperature was increased by $0.8^{\circ} \mathrm{C}\left(1.5^{\circ} \mathrm{F}\right)$, and rainfall depth, rainfall erosivity density, and $\mathrm{P}_{10 \mathrm{y}, 24 \mathrm{~h}}$ were each increased by $10 \%$. Evaluated individually and in combination, these changes all increased soil erosion, and most increased runoff as well. The combination of all these changes, when applied to a representative hillslope profile of Watershed 11 farmed with conventional tillage corn, increased sheet and rill erosion by $47 \%$ and runoff by $33 \%$. Thus, RUSLE2 provides results comparable to those predicted by process-based models, showing that a relative increase in precipitation-related climate variables is likely to result in a larger proportional change in soil erosion and sediment delivery. The above results assumed no change in corn yield. Under the current

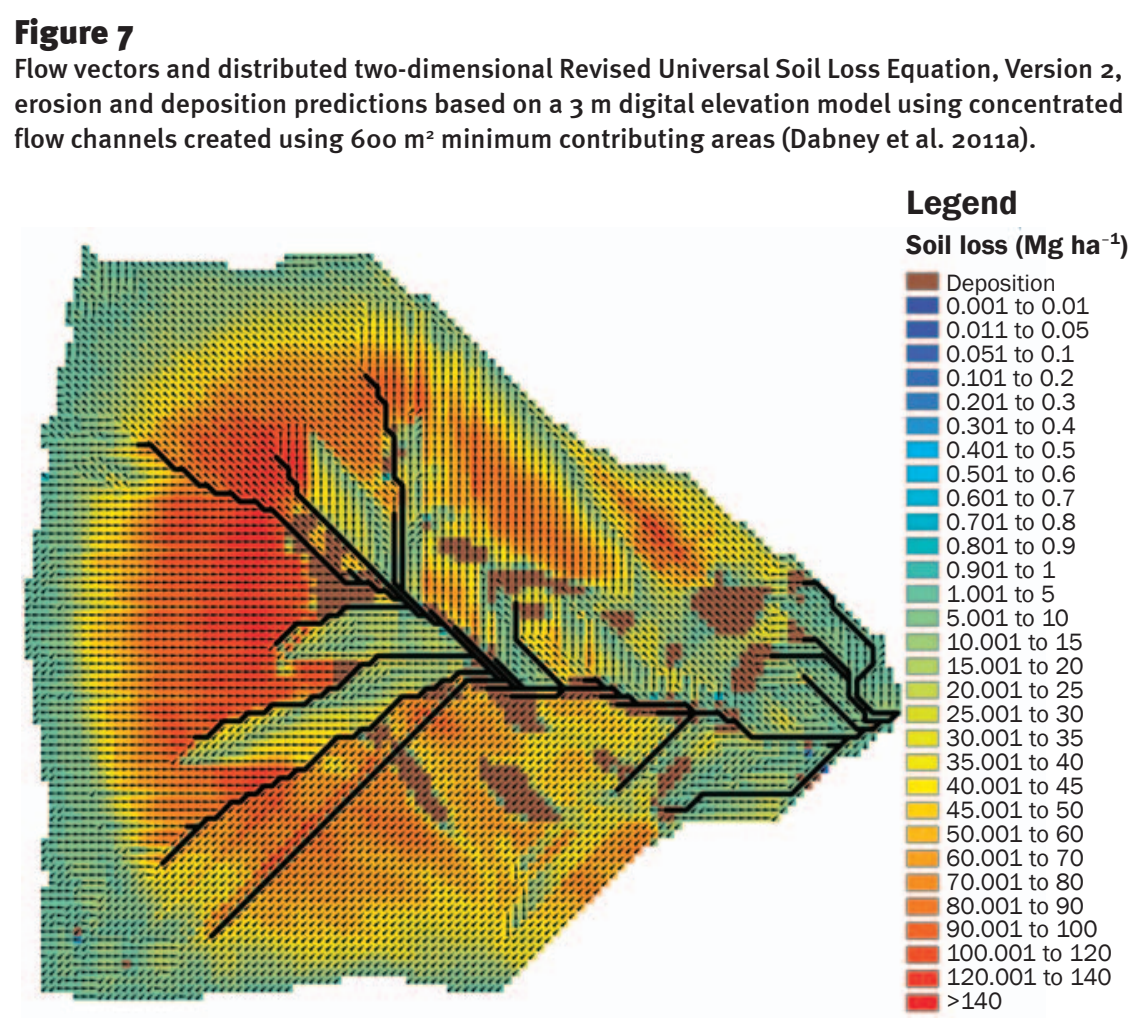

climate, a $10 \%$ increase in yield reduced estimated erosion by $8 \%$, whereas under a predicted future climate, the net effect is a $33 \%$ increase in estimated erosion. If the climate changes decreased corn yield by $10 \%$, the overall effect was to increase soil loss for conservation planning by $63 \%$. This considerable sensitivity of erosion estimates to $10 \%$ changes in climate variables is not a result of creating unrealistic climatic descriptions, as it is demonstrated that the modified climate records are similar to those existing within 70 to $150 \mathrm{~km}$ (43 to $93 \mathrm{mi}$ ) southeast of the research watershed.

Our results demonstrate that modest and expected changes in climate will significantly increase the risk of soil erosion. Improved conservation management will be an important part of successful adaptation. Recent enhancements to RUSLE2 allowing it to predict the size of extreme events have improved its utility as a conservation planning tool to assess the likelihood of success of conservation practices under current or future climates.

\section{References}

AgMIP (Agricultural Model Intercomparison and Improvement Project). 2010. http://www.agmip.org/. Angel, J.R., M.A. Palecki, and S.E. Hollinger. 2005. Storm precipitation in the United States. Part II: Soil erosion characteristics. Journal of Applied Meteorology 44:947-959.

Campbell, J.L., C.T. Driscoll, A. Pourmokhtarian, and K. Hayhoe. 2011. Streamflow response to past and projected future changes in climate at the Hubbard Brook Experimental Forest, New Hampshire, United States. Water Resources Research 45, W02514, doi:10.1029/2010WR009438.

Dabney, S.M., D.A.N. Vieira, and D.C. Yoder. 2011a. Effects of topographic feedback on erosion and deposition prediction. Paper \#11091. In International Symposium on Erosion and Landscape Evolution CD-Rom Proceedings, Anchorage, Alaska, September 18-21, 2011. St. Joseph, MI: American Society of Agricultural and Biological Engineers.

Dabney, S.M., and D.C. Yoder. 2012. Improved descriptions of herbaceous perennial growth and residue creation for RUSLE2. Agronomy Journal 104(3):771-784.

Dabney, S.M., D.C. Yoder, D.A.N. Vieira, and R.L. Bingner. 2011b. Enhancing RUSLE to include runoff-driven phenomena. Hydrological Processes 25:1373-1390.

Dai, A., F. Giorgi, and K.E. Trenberth. 1999. Observed and model-simulated diurnal cycles of precipitation over the contiguous United States. Journal of Geophysical Research 141(D6):6377-6402. 
Diodato, N., and G. Bellocchi. 2009. Assessing and modeling changes in rainfall erosivity at different climate scales. Earth Surface Processes and Landforms 34:969-980.

Dore, M.H.I. 2005. Climate change and changes in global precipitation patterns: What do we know? Environment International 31:1167-1181.

Eghball, B., J.E. Gilley, L.A. Kramer, and T.B. Moorman. 2000. Narrow grass hedge effects on phosphorus and nitrogen in runoff following manure and fertilizer application. Journal of Soil and Water Conservation 55(2):172-176.

Fiener, P., and K. Auerswald. 2003. Effectiveness of grassed waterways in reducing runoff and sediment delivery from agricultural watersheds. Journal of Environmental Quality 33:927-936.

Hatfield, J.L., K.J. Boote, B.A. Kimball, L.H. Ziska, R.C. Izaurralde, D. Ort, A.M. Thompson, and D. Wolfe. 2011. Climate impacts on Agriculture: Implications for crop production. Agronomy Journal 103(2):351-370.

Hayhoe, K., C.P. Wake, T.G. Huntington, L. Luo, M.D. Schwartz, J. Sheffield, E. Wood, B. Anderson, J. Bardbury, A. DeGaetano, T.J.Troy, and D. Wolfe. 2007. Past and future changes in climate and hydrological indicators in the US Northeast. Climate Dynamics 28:381-407.

Hollinger, S.E., J.R. Angel, and M.A. Palecki. 2002. Spatial distribution, variation, and trends in storm precipitation characteristics associated with soil erosion in the United States. Illinois State Water Survey Contract Report 2002-08. Champaign, IL: Illinois State Water Survey, Atmospheric Environment Section. http://www.sws. uiuc.edu/pubdoc/CR/ISWSCR2002-08.pdf.

Karlen, D.L., D.L. Dinnes, M.D. Tomer, D.W. Meek, C.A. Cambardella, and T.B. Moorman. 2009. Is no-tillage enough? A field-scale watershed assessment of conservation effects. Electronic Journal of Integrative Biosciences 7(2):1-24.

Moriasi D.N., J.G. Arnold, M.W. Van Liew, R.L. Bingner, R.D. Harmel, and T.L. Veith. 2007. Model evaluation guidelines for systematic quantification of accuracy in watershed simulations. Transactions of the American Society of Agricultural and Biological Engineers 50:885-900.

Nearing, M.A. 2001. Potential changes in rainfall erosivity in the US with climate change during the 21st century. Journal of Soil and Water Conservation 56(3):229-232.

Nearing, M.A.,V. Jetten, C. Baffaut, O. Cerdan, A. Couturier, M. Hernandez, Y. Le Bissonnais, M.H. Nichols, J.P. Nunes, C.S. Renschler, V. Souchère, and K. van Oost. 2005. Modeling response of soil erosion and runoff to changes in precipitation and cover. Catena 61(2-3):131-154.

Nunes, J.P., J. Seixas, J.J. Keizer, and A.J.D. Ferreira. 2009. Sensitivity of runoff and soil erosion to climate change in two Mediterranean watersheds. Part II: assessing impacts from changes in storm rainfall, soil moisture and vegetation cover. Hydrological Processes 23:1212-1220.

Rachman, A., S.H. Anderson, E.E. Alberts, A.L. Thompson, and C.J. Gantzer. 2008. Predicting runoff and sediment yield from a stiff-stemmed grass hedge system for a small watershed. Transactions of the American Society of Agricultural and Biological Engineers 51:425-432.

Renard, K.G., G.R. Foster, G.A. Weesies, D.K. McCool, and D.C. Yoder (coordinators). 1997. Predicting Soil Erosion by Water: A Guide to Conservation Planning with the Revised Universal Soil Loss Equation (RUSLE). Agricultural Handbook 703. Washington, DC: USDA Agricultural Research Service. http://www.ars.usda.gov/ SP2UserFiles/Place/64080530/RUSLE/AH_703.pdf

Sauerborn, P., A. Klein, J. Botschek, and A. Skowronek. 2009. Future rainfall erosivity derived from large-scale climate models - Methods and scenarios for a humid region. Geoderma 93:269-276.

SWCS (Soil and Water Conservation Society). 2007. Planning for Extremes. Ankeny, IA: Soil and Water Conservation Society.

Tebaldi, C., K. Hayhoe, J.M. Arblaster, and G.A. Meehl. 2006. Going to the extremes, and intercomparison of modelsimulated historical and future changes in extreme events. Climatic Change 79:185-211.

Tomer, M.D., T.B. Moorman, J.L. Kovar, D.E. James, and M.R. Burkhart. 2007. Spatial patterns of sediment and phosphorus in a riparian buffer in Western Iowa. Journal of Soil and Water Conservation 62(5):329-338.

USDA ARS (Agricultural Research Service). 2008. Draft Science Documentation, Revised Universal Soil Loss Equation Version 2. Washington, DC: USDA Agricultural Research Service. http://www.ars.usda.gov/sp2UserFiles/ Place/64080510/RUSLE/RUSLE2_Science_Doc.pdf.

USDA ARS. 2011. Rainfall Intensity Summarization Tool (RIST). Washington, DC: USDA Agricultural Research Service. http://www.ars.usda.gov/Research/docs. htm? docid $=3251$.

USDA NRCS (Natural Resources Conservation Service). 2012a. Revised Universal Soil Loss Equation, Version 2 (RUSLE2) Official NRCS Database. http://fargo.nserl. purdue.edu/rusle2_dataweb/RUSLE2_Index.htm.

USDA NRCS. 2012b. Web Soil Survey. http://websoilsurvey. nrcs.usda.gov.

Yu, B. 2005. Adjustment of CLIGEN parameters to generate precipitation change scenarios in southeastern Australia. Catena 61:196-209.

Zhang, Y.G., M.A. Nearing, X.C Zhang, Y. Xie, H. Wei. 2010. Projected rainfall erosivity changes under climate change from multimodel and multiscenario projections in Northeast China. Journal of Hydrology 384(1-2):97-106. 